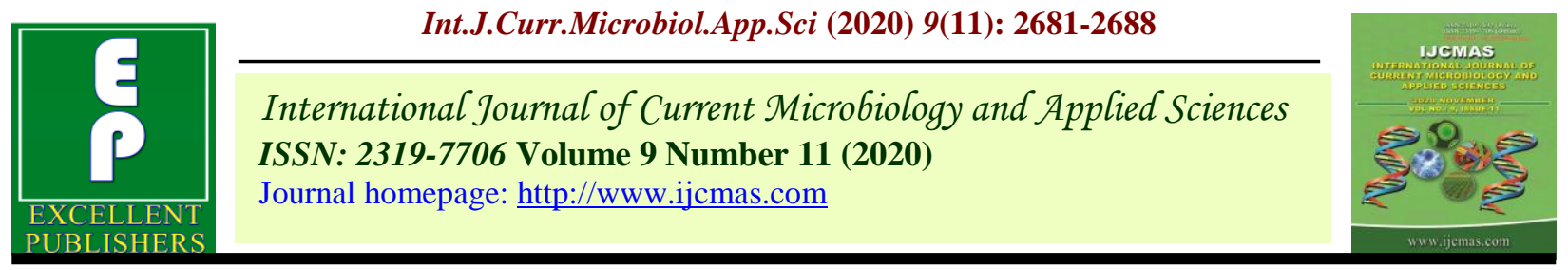

Original Research Article

https://doi.org/10.20546/ijcmas.2020.911.325

\title{
In vitro Efficacy of Bio-Control Agents against Castor Wilt Caused by Fusarium oxysporum f. sp. ricini
}

\author{
V. Apurva ${ }^{1}$, K. Karuna ${ }^{1}$, K. B. Palanna ${ }^{2}$, Yamanura ${ }^{3}$ and R. Mohan Kumar ${ }^{3}$ \\ ${ }^{1}$ Department of Plant Pathology, College of Agriculture, UAS, \\ GKVK, Bengaluru-560065, India \\ ${ }^{2}$ All India Coordinated Research Project on Small millets, ${ }^{3}$ All India Coordinated Research \\ Project on Castor, ZARS, UAS, GKVK, Bengaluru-560065, India \\ *Corresponding author
}

\section{A B S T R A C T}

Keywords

Castor, Fusarium oxysporum f. sp. ricini, Dual culture technique, Per cent inhibition,

Trichoderma,

Bacillus

Article Info

Accepted:

20 October 2020

Available Online:

10 November 2020
Wilt caused by Fusarium oxysporum f. sp. ricini poses a major problem in all the castor growing areas of the country. Since the soil borne disease can be effectively controlled by biocontrol agents, the present study was conducted to know the antagonistic activity of different bioagents in vitro at department of Plant Pathology, College of Agriculture, UAS, GKVK, Bengaluru during 2019-20. Eight fungal and eight bacterial bio-agents were evaluated using dual culture method. Th14 strain of Trichoderma harzianum exhibited highest $(80.47 \%)$ inhibition of mycelial growth of $F$. oxysporum f. sp. ricini while the remaining strains of both $T$. harzianum and $T$. viride were able to control the pathogen at least by 72 per cent under in vitro conditions. In case of bacterial antagonists Bacillus velezensis ( $\mathrm{P} 42)$ showed a good inhibition of 58.89 per cent over the rest.

\section{Introduction}

Castor (Ricinus communis L.) the non-edible oilseed crop belongs to family Euphorbiaceae which can be cultivated under varied climatic conditions of tropical, subtropical and temperate regions, however largely restricted to tropical countries. Evidences revealed that castor is native to Ethiopian region of tropical East Africa (Weiss, 1971) and India (Moshkin, 1986). The richness of ricinoleic acid in castor oil has given it immense industrial value in the world. It is being cultivated in about 30 diverse countries on saleable scale, among these India, Brazil, China, Russia, Thailand and Philippines are the most vital castor growing countries. India is world leader in area, 12.2 lakh tonnes of castor is being produced from 7.62 lakh ha with an average yield of $1.6 \mathrm{t} \mathrm{ha}^{-1}$ (Yamanura and Mohan Kumar R, 2020). India is the global leader in castor seed production and 
also in export, contributing 70 per cent of world castor production and meets about 90 per cent of world castor oil demand. Among the soil borne disease castor wilt caused by Fusarium oxysporum f. sp. ricini, is a potential threat for large scale cultivation of the crop in the country since the disease can result in a yield loss of upto 80 per cent. Internal browning or blackening of the xylem vessels is the characteristic symptom leading to sickly appearance and necrosis of the infected tissues. Intensive crop cultivation without proper crop rotation leads to endemic development of wilt resulting in a significant loss of yield in all castor hybrids (Dange et al., 1997). Since it is a soil borne as well as seed borne to some extent, the management requires an integrated approach which should include biocontrol along with conventional control strategies (Prasad et al., 2019). Keeping in view the importance of crop and disease management the present in vitro bioassay was conducted to assess the efficacy of antagonists in inhibition of $F$. oxysporum $\mathrm{f}$. sp. ricini.

\section{Materials and Methods}

The bio-agents used in present study were obtained from Department of Plant Pathology, College of Agriculture, UAS, Bangalore and IIHR, Hessaraghatta, Bengaluru, to study their antagonistic activity against Fusarium oxysporumf. sp. ricini by following dual culture technique (Table 1).

The fungal and bacterial bio-agents collected were sub-cultured on PDA and Nutrient Agar in order to obtain actively growing fresh mycelium for carrying out dual culture studies. Twenty $\mathrm{ml}$ of sterilized PDA media was poured into sterile Petri plates. Seven days old culture of pathogen and fungal bioagents was cut into five $\mathrm{mm}$ discs using sterile cork borer and both were placed at equidistance and exactly opposite to each other on the solidified PDA media near the peripheral end of the same plate. Likewise, for bacterial bio-agents a loop full of bacterial antagonists were streaked at one end of the plate and the disc of pathogen was placed on the opposite end of the same plate. A control plate was maintained by placing only the fungal pathogen at the centre of the Petri plate and incubated at $27 \pm 1^{\circ} \mathrm{C}$. Each treatment was replicated thrice. The observation on the radial growth of the pathogen was taken when the growth of the pathogen was full in the control plate and per cent inhibition of the growth of pathogen against control was calculated using the equation given by Vincent (1947).

$\mathrm{I}=\frac{\mathrm{C}-\mathrm{T}}{\mathrm{C}} \times 100$

Where,

$\mathrm{I}=$ Per cent inhibition of mycelial growth

$\mathrm{C}=$ Growth of mycelium in control.

$\mathrm{T}=$ Growth of mycelium in treatment.

\section{Results and Discussion}

The fungal and bacterial bio-agents were screened against Fusarium oxysporum f. sp. ricini in vitro by dual culture technique as described in material and methods to know their antagonistic effect. The list of bioagents used were given in table 1 .

The fungal antagonists such as Trichoderma harzianum, $T$. viride and their strains were used in the study. The radial growth and per cent inhibition of mycelial growth of fungus was calculated and results are furnished in Table 2; Fig. 1 and Plate 1. The results presented in the table reveal that all the strains of Trichoderma harzianum, T. viride showed more or less equal inhibition of mycelial growth of the pathogen and found effective in suppressing the pathogen under in vitro. The 
highest mycelial growth inhibition of 80.47 per cent was observed in Th14 strain of $T$. harzianum that was on par with Th-41 (79.81\%), Th-B2 (79.48\%), Tv-1 (79.35\%) and Th-55 (78.44\%). Moderate inhibition was by $\mathrm{Tv}-2$ (76.43\%) and Th-56 (75.99\%) whereas the least inhibition was recorded in Tv-3 (72.77\%).

The eight bacterial bio control agents tested against Fusarium oxysporum f. sp. ricini showed significant difference with respect to per cent inhibition of mycelia of the pathogen. Bacillus velezensis ( $\mathrm{P} 42)$ exhibited the highest growth inhibition of 58.89 per cent. Next in the order were Bacillus pumilus (51.84\%), Bacillus velezensis (A6) (47.61\%), Azospirillum brasilense (37.99\%), Bacillus subtilis (29.89\%), Pseudomonas fluorescens (28.22\%) and Bacillus megaterium (27.65\%), while the lowest inhibition of 26.7 per cent was seen in case of Azatobacter chroococcum (Table 3; Fig. 2 \& Plate 2).

It is evident from the results that fungal antagonists were superior to bacterial antagonists in inhibiting the growth of the pathogen. The varied potential of antagonistic activity of these bio-agents may be due various mechanisms like hyperparasitism, competition and production of antibiotics which has been well established and reported by Baker and Cook (1982). Ali and Nadarajah (2014) documented that the principle cause for inhibition of mycelial growth of pathogen by Trichoderma was coiling of pathogen hyphae by Trichoderma. Kalaivani et al., (2014) reported that the cell wall degrading enzyme endochitinase produced by Trichoderma spp. is responsible for breakdown of cell wall (Chitin) of pathogen.

Table.1 List of bacterial bio-agents used for in vitro studies

\begin{tabular}{|l|l|l|l|}
\hline Sl.No. & Fungal bio-agents & SI.No. & Bacterial bio-agents \\
\hline 1 & Trichoderma viride $(\mathrm{Tv})$ & 1 & Pseudomonas fluorescens \\
\hline 2 & Trichoderma viride $(\mathrm{Tv}-1)$ & 2 & Bacillus megaterium \\
\hline 3 & Trichoderma viride $(\mathrm{Tv}-3)$ & 3 & Bacillus pumilus \\
\hline 4 & Trichoderma harzianum $\left(\mathrm{Th}-\mathrm{B}_{2}\right)$ & 4 & Bacillus velezensis $(\mathrm{A6})$ \\
\hline 5 & Trichoderma harzianum $(\mathrm{Th}-14)$ & 5 & Bacillus velezensis $(\mathrm{P} 42)$ \\
\hline 6 & Trichoderma harzianum $(\mathrm{Th}-41)$ & 6 & Bacillus subtilis \\
\hline 7 & Trichoderma harzianum $(\mathrm{Th}-55)$ & 7 & Azatobacte rchroococcum \\
\hline 8 & Trichoderma harzianum $(\mathrm{Th}-56)$ & 8 & Azospirillum brasilense \\
\hline
\end{tabular}


Table.2 Effect of antagonistic activity fungal bio agents against Fusarium oxysporum f. sp. ricini under in vitro conditions

\begin{tabular}{|c|c|c|c|}
\hline Sl. No. & Bio agents & $\begin{array}{l}\text { Radial growth of } \\
\text { pathogen }(\mathbf{m m})^{*}\end{array}$ & $\begin{array}{l}\text { Per cent inhibition } \\
\text { over control }(\%) *\end{array}$ \\
\hline 1 & Trichoderma viride $(\mathrm{Tv}-1)$ & 18.57 & $\begin{array}{c}79.35 \\
(62.98)\end{array}$ \\
\hline 2 & T. viride $(\mathrm{Tv}-2)$ & 21.21 & $\begin{array}{c}76.43 \\
(60.97)\end{array}$ \\
\hline 3 & T. viride (Tv-3) sirsi type & 24.50 & $\begin{array}{c}72.77 \\
(58.54)\end{array}$ \\
\hline 4 & T. harzianum $\left(\mathrm{Th}-\mathrm{B}_{2}\right)$ & 18.45 & $\begin{array}{c}79.48 \\
(63.07)\end{array}$ \\
\hline 5 & T. harzianum (Th-41) & 18.16 & $\begin{array}{c}79.81 \\
(63.30)\end{array}$ \\
\hline 6 & T. harzianum(Th-14) & 17.56 & $\begin{array}{c}80.47 \\
(60.80)\end{array}$ \\
\hline 7 & T. harzianum(Th-56) & 21.60 & $\begin{array}{c}75.99 \\
(62.67)\end{array}$ \\
\hline 8 & T. harzianum(Th-55) & 19.40 & $\begin{array}{c}78.44 \\
(60.33)\end{array}$ \\
\hline 9 & Control & 90.00 & $\begin{array}{c}0.00 \\
(0.30)\end{array}$ \\
\hline & S.Em \pm & 0.79 & 0.87 \\
\hline & C.D. $(p 0.01)$ & 2.36 & 2.63 \\
\hline
\end{tabular}

*Mean of three replications.

Note: Figures in the parenthesis are arc sine transformed values.

Fig.1 Antagonistic activity of fungal bio agents on mycelia growth and inhibition against Fusarium oxysporum f. sp. ricini

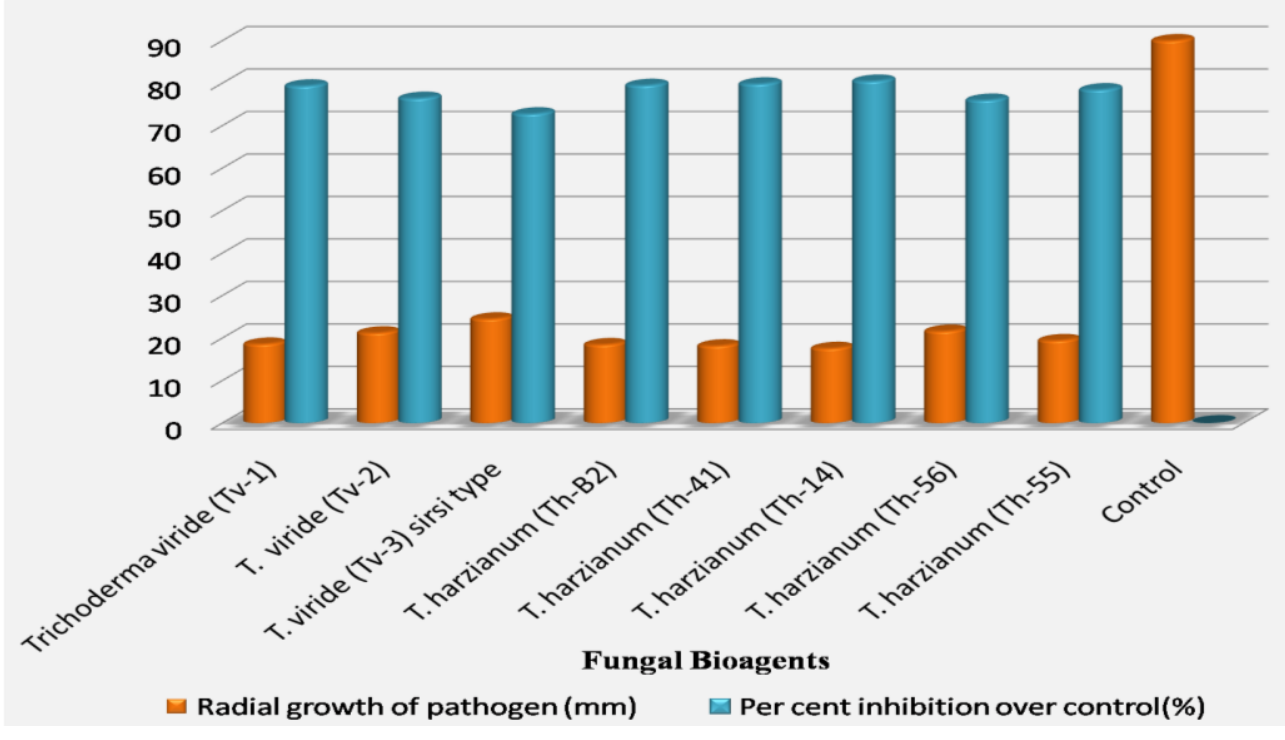


Table.3 Effect of antagonistic activity of bacterial bio agents against Fusarium oxysporum f. sp. ricini under in vitro conditions

\begin{tabular}{|c|c|c|c|}
\hline Sl. No. & Bio agents & $\begin{array}{l}\text { Radial growth of } \\
\text { pathogen }(\mathrm{mm}) *\end{array}$ & $\begin{array}{l}\text { Per cent inhibition } \\
\text { over control } *(\%)\end{array}$ \\
\hline 1 & Bacillus subtilis & 63.09 & $\begin{array}{c}29.89 \\
(33.14)\end{array}$ \\
\hline 2 & Bacillus megaterium & 65.11 & $\begin{array}{c}27.65 \\
(31.72)\end{array}$ \\
\hline 3 & Azatobacter chroococcum & 65.96 & $\begin{array}{c}26.70 \\
(31.10)\end{array}$ \\
\hline 4 & Pseudomonas fluorescens & 64.60 & $\begin{array}{c}28.22 \\
(32.07)\end{array}$ \\
\hline 5 & Azospirillumbrasilense & 55.80 & $\begin{array}{c}37.99 \\
(38.05)\end{array}$ \\
\hline 6 & Bacillus velezensis( $\mathrm{P} 42)$ & 36.99 & $\begin{array}{c}58.89 \\
(50.12)\end{array}$ \\
\hline 7 & Bacillus velezensis(A6) & 47.14 & $\begin{array}{c}47.61 \\
(43.63)\end{array}$ \\
\hline 8 & Bacillus pumilus & 43.33 & $\begin{array}{c}51.84 \\
(46.05)\end{array}$ \\
\hline 9 & Control & 90.00 & $\begin{array}{c}0.00 \\
(0.30)\end{array}$ \\
\hline & S.Em \pm & 0.86 & 0.95 \\
\hline & C.D. $(\mathrm{p} 0.01)$ & 2.57 & 2.86 \\
\hline
\end{tabular}

*Mean of three replications.

Note: Figures in the parenthesis are arc sine transformed value.

Fig.2 Antagonistic activity bacterial bio agents on mycelia growth and inhibition against Fusarium oxysporum f. sp. ricini

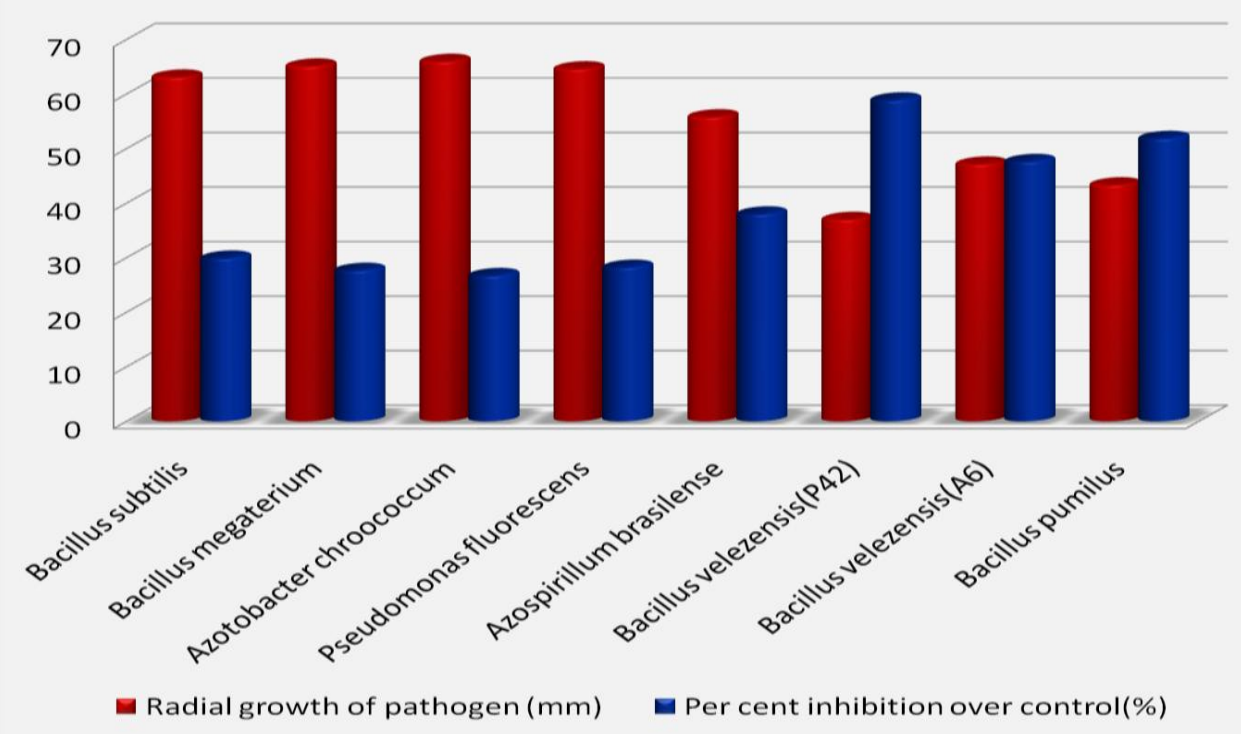


Plate.1 In vitro evaluation of fungal bio agents against Fusarium oxysporum f. sp. ricini

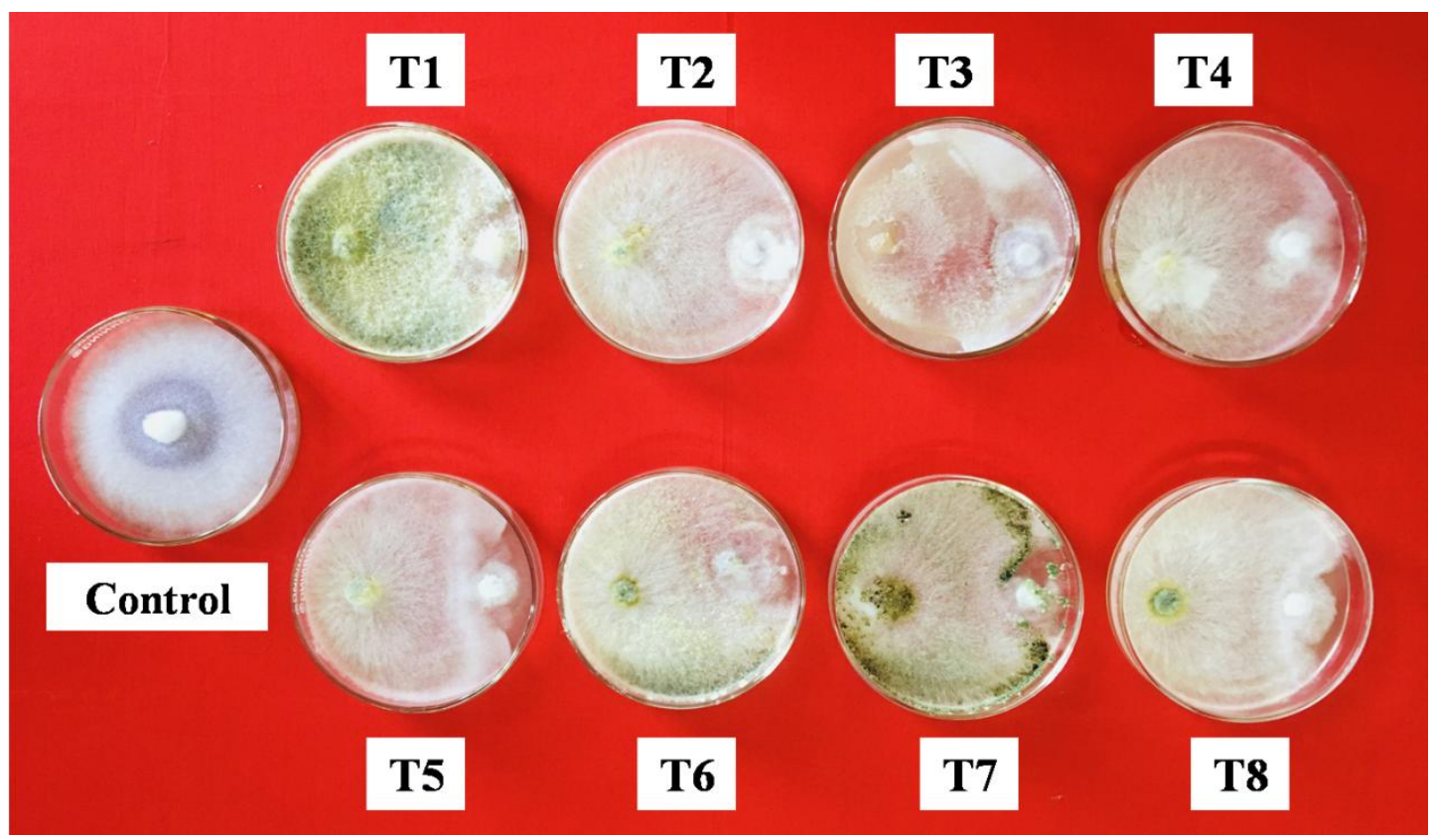

T1- Trichoderma viride (Tv-1)

$\mathrm{T} 2-T$. viride $(\mathrm{Tv}-2)$

T3- T. viride( $\mathrm{Tv}-3)$ sirsi type
T4- T. harzianum(Th-B2)

T5- T. harzianum (Th-41)

T6- T. harzianum(Th-14)
T7- T. harzianum(Th-56)

T8- T. harzianum(Th-55)

Plate.2 In vitro evaluation of bacterial bio agents against Fusarium oxysporum f. sp. ricini

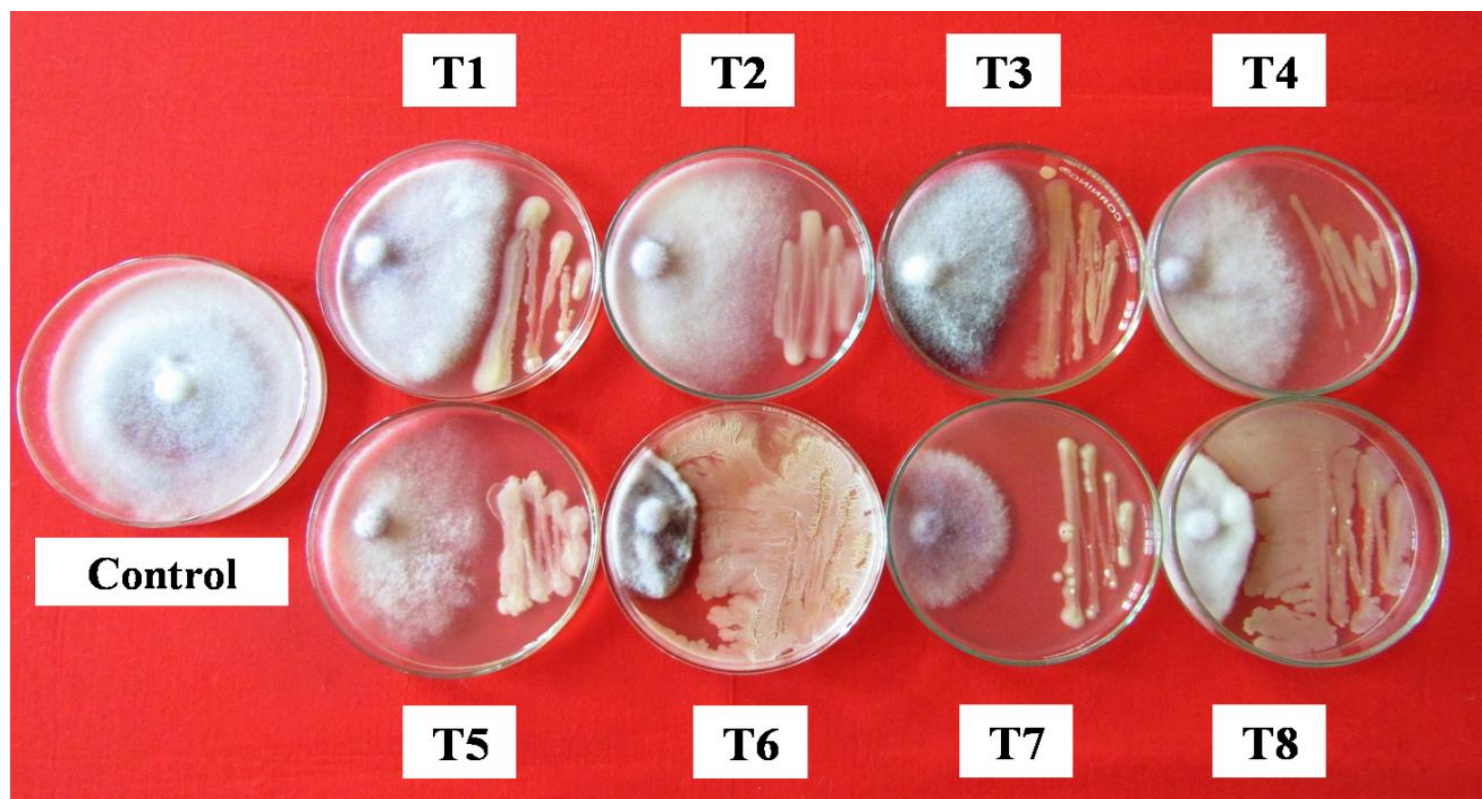

T1- Bacillus subtilis

T2- Bacillus megaterium

T3-Azotobacter chroococcum
T4- Pseudomonas fluorescens T5- Azospirillum brasilense T6- Bacillus velezensis (P42)
T7- Bacillus velezensis (AO) T8-Bacillus pumilus 
Shalini et al., (2017) reported that out of 14 native and commercial bio-agents tested against Fusarium oxysporumf. sp. ricini, native isolates like Trichoderma viride (DOR $\mathrm{Tv}$ ), T. harzianum (DOR Th) and commercial isolates $T$. viride (Trichogen-T) and $T$. viride (Bhoomika) significantly controlled the pathogen by showing 100 per cent inhibition. Similarly, several other workers (Pushpavathi et al., 1998; Meghwal et al., 2014; Ajay and Naik, 2013 and Shankar et al., 2016) also described that Trichoderma spp. were very effective against $F$. oxysporum f. sp. ricini.

In this study, Bacillus velezensis and Bacillus pumilus were found superior over other bacterial species in controlling the test pathogen. This may be due to the production of several antibiotics like substances such as Kanamycin, lipopeptide and fengycin (Stabb et al., 1994), Zwittermycin-A (He et al., 1994). The results obtained in case of bacterial bio-agent is in agreement with the previous researchers Ajay and Naik (2013) and Shankar et al., (2016) against $F$. oxysporum f. sp. ricini.

Fungal and bacterial bioagents, used in the current study were found effective in suppression of $F$. oxysporum f.sp. ricini pathogen under in-vitro and the identified potential bio-agents can be carried further for field evaluation and this preliminary data may help in designing IDM for castor wilt.

\section{References}

Ajay, K. K. and Naik, K. L., 2013. In vitro evaluation of biocontrol agents against isolated wilt pathogen of castor (Ricinus communis L.) Mysore J. Agric. Sci. 49(2): 221-223.

Ali, H. and Nadarajah, K., 2014. Evaluating the efficacy of Trichoderma spp and Bacillus subtilis as biocontrol agents against Magnaporthe grisea in rice.
Aus. J. Crop. Sci. 8(9): 1324-1335.

Baker, K. F. and Cook, R. J., 1974. Biological Control of Plant Pathogens, In: Freeman, San Francisco, California, pp. 433.

Dange, S. R. S., Desai, A. G. and Patel, D. B., 1997. Management of wilt of castor in Gujarat state of India, In: International Conference on Integrated Plant Disease Management for sustainable Agriculture, IARI, New Delhi, India, pp. 107.

He, H. L. A., Laura, A. S. S., Handelsman, J. and Clardy,J., 1994. Zwittermicin A: an antifungal and plant protection agent from Bacillus cereus. Tetrahedron Lett. 35:2499.

Kalaivani, N., Hamdia, Z. A. and Nurfarahana, S. O., 2014. The isolation and characterization of an endochitinase gene from a Malaysian isolate of Trichoderma sp. Aust. J. Crop Sci.,8(5): 711-721.

Moshkin, V. A., 1986. Castor. Amerind Publishing Co. Pvt. Ltd. New Delhi.

Meghwal, M. L., Jambhulkar, P. P. And Solanki, V. A., 2014.Antogonistic potential of Trichoderma isolates against castor wilt Pathogen ( $F$. oxysporumf. sp.ricini). BIOINFOLET. 11(4B): 1115-1119.

Prasad, S. L. M., Raoof, M. A., Gayatri, B., Anjani, K., Lavanya, C., Prasad, R. D., and Senthilvel, S., 2019. Wilt disease of castor: an overview. Indian Phytopathol. 72 (2):1-11.

Pushpavathi, B., Sarwar, H. A. K, Raoof, M. A. and Babu, R. R, 1998. Management of wilt disease in castor. Indian J. Plant Prot. 26 (2): 177-180.

Shalini, Y. L., Vidya, S. B., Giribabu, P and Krishna, R., 2017. Efficacy of fungal versus bacterial bioagents on fusarium wilt of Castor. Int. J. Curr. Microbiol. App. Sci., 6(11): 1230-1239.

Shankar, G. V., Kumar, M. N. V., Priya, P. B. 
and Shanker, A. S., 2016. In vitro evaluation of fungicides and bio-control agents against Fusarium oxysporum f. sp. Ricini. Progressive Research - An International Journal, 11(7): 4775 4779.

Stabb, E. V. L. M., Jacobson, J. and Handelsman, L., 1994. Zwittermicin Aproducing strains of Bacillus cereus from diversion soils. App. Environ. Microbiol., 60: 44-52.
Vincent, J. M., 1947, Distribution of fungal hyphae in the presence of certain inhibitors. Nature. 159: 850.

Yamanura and R Mohan Kumar, 2020. Study of genetic variability, path coefficient and genetic diversity in castor (Ricinus communis L.). The Pharma Innovation Journal, 9(8): 285-292.

Weiss, E. A., 1971, Castor, Sesame and Safflower. Leonard Hill, London, pp. 31-99.

\section{How to cite this article:}

Apurva, V., K. Karuna, K. B. Palanna, Yamanura and Mohan Kumar, R. 2020. In vitro Efficacy of Bio-Control Agents against Castor Wilt Caused by Fusarium oxysporum f. sp. ricini. Int.J.Curr.Microbiol.App.Sci. 9(11): 2681-2688.

doi: https://doi.org/10.20546/ijcmas.2020.911.325 